\title{
Analysis of TIR- and non-TIR-NBS-LRR disease resistance gene analogous in pepper: characterization, genetic variation, functional divergence and expression patterns
}

Hongjian Wan, Wei Yuan, Qingjing Ye, Rongqing Wang, Meiying Ruan, Zhimiao Li, Guozhi Zhou, Zhuping Yao, Jing Zhao, Shujun Liu and Yuejian Yang*

\begin{abstract}
Background: Pepper (Capsicum annuum L.) is one of the most important vegetable crops worldwide. However, its yield and fruit quality can be severely threatened by several pathogens. The plant nucleotide-binding site (NBS)-leucine-rich repeat (LRR) gene family is the largest class of known disease resistance genes (R genes) effective against such pathogens. Therefore, the isolation and identification of such $\mathrm{R}$ gene homologues from pepper will provide a critical foundation for improving disease resistance breeding programs.

Results: A total of $78 \mathrm{R}$ gene analogues (CaRGAs) were identified in pepper by degenerate PCR amplification and database mining. Phylogenetic tree analysis of the deduced amino acid sequences for 51 of these CaRGAs with typically conserved motifs ( P-loop, kinase-2 and GLPL) along with some known R genes from Arabidopsis and tomato grouped these CaRGAs into the non-Toll interleukin-1 receptor (TIR)-NBS-LRR (CaRGAs I to IV) and TIR-NBS-LRR (CaRGAs V to VII) subfamilies. The presence of consensus motifs (i.e. P-loop, kinase-2 and hydrophobic domain) is typical of the non-TIR- and TIR-NBS-LRR gene subfamilies. This finding further supports the view that both subfamilies are widely distributed in dicot species. Functional divergence analysis provided strong statistical evidence of altered selective constraints during protein evolution between the two subfamilies. Thirteen critical amino acid sites involved in this divergence were also identified using DIVERGE version 2 software. Analyses of non-synonymous and synonymous substitutions per site showed that purifying selection can play a critical role in the evolutionary processes of non-TIR- and TIR-NBS-LRR RGAs in pepper. In addition, four specificity-determining positions were predicted to be responsible for functional specificity. QRT-PCR analysis showed that both salicylic and abscisic acids induce the expression of CaRGA genes, suggesting that they may primarily be involved in defence responses by activating signaling pathways.
\end{abstract}

Conclusion: The identified CaRGAs are a valuable resource for discovering $R$ genes and developing RGA molecular markers for genetic map construction. They will also be useful for improving disease resistance in pepper. The findings of this study provide a better understanding of the evolutionary mechanisms that drive the functional diversification of non-TIR- and TIR-NBS-LRR R genes in pepper.

\footnotetext{
* Correspondence: hzyyj@yahoo.com.cn

Institute of Vegetables, Zhejiang Academy of Agricultural Sciences,

Hangzhou 310021, People's Republic of China
} 


\section{Background}

Plant disease resistance genes ( $R$ genes) are important components of the genetic resistance mechanism in plants $[1,2]$. Over the past decade, several $R$ genes conferring resistance to a wide spectrum of plant pathogens, including bacteria, fungi, oomycetes, viruses and nematodes, have been cloned from different plant species [2-5]. Sequence analyses revealed that these proteins share a high degree of homology and have a number of conserved motifs. These include a nucleotide-binding site (NBS), a leucine-rich repeat (LRR) region, a motif homologous to the cytoplasmic domains of the Drosophila Toll protein and the mammalian interleukin-1 receptor (TIR), a coiled-coil (CC) or leucine zipper structure, a transmembrane domain (TM) and a protein kinase domain [6]. Although a wide range of pathogens are involved, these $\mathrm{R}$ genes encode a limited set of proteins that can be classified into several superfamilies, including NBS-LRR, a receptor-like kinase, LRR-TM and TM-CC [2,7].

The NBS-LRR class of $R$ genes can be divided into two subfamilies (TIR-NBS-LRR and non-TIR-NBS-LRR) based on the features of their $\mathrm{N}$-terminal structure $[2,8]$. These two subfamilies can also be distinguished (95\% accuracy) by the last residue, D (Aspartate) or W (Tryptophan), of the conserved kinase-2 motif within the NBS domain [9]. The former corresponds to the TIR-NBSLRR subfamily, whereas the latter corresponds to the non-TIR-NBS-LRR subfamily of $\mathrm{R}$ genes. The 'NBS' and 'LRR' domains in the NBS-LRR $R$ genes have different roles during host-pathogen recognition. The highly conserved NBS domains can bind and hydrolyze ATP or GTP [10], whereas the LRR motif is typically involved in protein-protein interactions and is responsible for recognition specificity $[2,11,12]$.

To date, eight conserved motifs have been identified in the NBS domain of plant non-TIR- and TIR-NBS-LRR R genes, including P-loop, kinase-2, kinase-3a, GLPL, RNBS-A-TIR, RNBS-D-TIR, RNBS-A-non-TIR and RNBS-D-non-TIR [8]. The first four conserved motifs are common in the TIR and non-TIR-NBS-LRR subfamilies. The RNBS-A-TIR and RNBS-D-TIR motifs are specific to the TIR-NBS-LRR subfamily. The remaining two motifs, RNBS-A-non-TIR and RNBS-D-non-TIR, belong to the non-TIR-NBS-LRR subfamily. These highly conserved motifs within the NBS domain occur across different plant species, making it possible to isolate $\mathrm{R}$ gene analogues (RGAs) from other crops using degenerate polymerase chain reaction (PCR) [13-19]. At present, more than 1600 NBS-LRR-type RGAs have been amplified via PCR from a wide range of plant species, and they have been arranged in clusters similar to $\mathrm{R}$ genes in plant genomes $[5,20]$. Some of these are closely linked to known $\mathrm{R}$ gene loci or form a part of the R genes [21-23].
In recent years, the evolutionary patterns of NBS-LRR $R$ genes have been investigated extensively in different plant species. For example, in annual species, such as Arabidopsis and rice, studies have shown that tandem and segmental gene duplication, gene conversion, unequal crossing-over, ectopic recombination and diversifying selection seem to be the primary evolutionary modes of NBS-LRR R genes [3,24-27]. In woody perennial species (e.g. grapevine and poplar), tandem gene duplication and recombination play major roles in NBS-LRR R gene expansion [28]. Point mutations, small insertions or deletions and gene loss have been proposed as the primary mechanisms by which NBS-LRR $R$ genes evolve $[29,30]$. Therefore, the evolution of plant NBS-LRR $R$ genes appears to be a complex process.

Pepper (Capsicum annuum L.), a member of the botanical family Solanaceae, is an important vegetable crop worldwide. However, its production is affected because it is prone to many diseases. At present, three $\mathrm{R}$ genes conferring resistance to strains of Xanthomonas campestris $p v$. vesicatoria and root-knot nematodes have been identified from pepper [31-33]. Of them, two genes (Bs2 and $\mathrm{CaMi}$ ) encode motifs characteristic of the NBS-LRR class of resistance genes. Moreover, some RGAs in pepper have been identified by modified amplified fragment length polymorphisms, NBS profiling and specific PCR amplification with primers designed from conserved regions of the NBS domain [34-37]. However, no detailed analysis of RGA characteristics is currently available. In this paper, we followed a PCR-based protocol using $\mathrm{R}$ gene-specific degenerate primers and data mining to identify and characterize the NBS-LRR CaRGAs and identify putative $\mathrm{R}$ genes in pepper. We also analyzed the genetic variations and phylogeny in pepper. Functional divergence analysis provided statistical evidence for altered selective constraints during protein evolution between the two subfamilies and identified some critical amino acid sites involved in this functional divergence. Analyses of non-synonymous (Ka) and synonymous (Ks) substitutions per site revealed a purifying selection in the evolutionary processes of non-TIR- and TIR-NBS-LRR CaRGAs in pepper. Several specificitydetermining positions (SDPs) responsible for functional specificity were also predicted. Finally, the expression of representative CaRGAs was analysed in response to hormones and in different organs.

\section{Results and discussion}

\section{Identification of non-TIR- and TIR-NBS-LRR CaRGAs} in pepper

Candidate non-TIR- and TIR-NBS-LRR CaRGAs were identified in pepper using two approaches, PCR amplification with degenerate primers and database mining. Two pairs of degenerate primers, previously designed 
based on conserved domains (P-loop and GLPL regions) among known NBS-LRR $R$ genes from other plant species [37-39], were used. Two bands of the predicted size ( $500 \mathrm{bp})$ were amplified using the genomic DNA of pepper (Additional file 1). The bands were then excised from agarose gels and cloned. A total of fifty clones were randomly selected for sequencing, twenty-four of which were highly homologous to NBS-LRR sequences or known $\mathrm{R}$ genes from other plant species. These sequences were designated as NBS-LRR CaRGAs. The remaining clones were homologous to either a putative polyprotein or a hypothetical LRR protein. This finding suggests that degenerate PCR amplification is a very effective method for isolating potential CaRGAs from pepper.

A total of fifty-four CaRGAs were identified using the key word 'Capsicum resistance gene' in a search of the National Center for Biotechnology Information (NCBI) non-redundant protein database (http://www.ncbi.nlm. nih.gov/). A total of seventy-eight CaRGAs were obtained using these two methods. Among the seventyeight CaRGAs, fifty-five had uninterrupted open reading frames (seventeen from amplified products, thirty-eight from data mining) and twenty-three CaRGAs had stop codons in the reading frames. These CaRGAs may be non-functional genes. Hence, they were excluded from further analysis. Moreover, two R genes reported previously were selected for further analysis [32,33]. In addition, more than one hundred and seventy and four hundred NBS-LRR R genes from Arabidopsis and rice $[3,26]$, respectively, were used to retrieve potential $\mathrm{R}$ genes or CaRGAs from pepper. However, no novel CaRGAs or $\mathrm{R}$ genes were found. The nucleotide and amino acid sequences of all these pepper CaRGAs are listed in Additional file 2.

\section{Sequence analysis and phylogenetic relationship between non-TIR- and TIR-NBS-LRR RGAs}

BLASTX searches revealed that the fifty-seven CaRGAs had a certain degree of identity with known $\mathrm{R}$ genes as well as some RGAs from other plant species. They contained the conserved NB-ARC (nucleotide-binding adaptor shared by Apaf-1, R proteins and Ced-4) domain of known $\mathrm{R}$ genes [40-42]. Further analysis indicated that these CaRGAs, except for CaRGA54 (AF513549), CaRGA55 (FJ605104), CaRGA56 (FJ605105) and CaRGA57 (FJ605107), also included typically conserved motifs such as P-loop, kinase- 2 and GLPL.

To investigate the evolutionary relationships among the NBS-LRR CaRGAs of pepper, phylogenetic trees were constructed based on the region between the Ploop and GLPL motifs using Molecular Evolutionary Genetics Analysis (MEGA) 5.0 software [43]. The aforementioned four CaRGAs were excluded from subsequent analyses because they lacked conserved P-loop and GLPL motifs. Thus, a total of fifty-three CaRGAs of pepper were used for phylogenetic tree construction. Six known R genes (RPM1, Gpa2, L6, M, N and Prf), downloaded from the GenBank database, were also included in the analysis. The phylogenetic tree is shown in Figure 1. Two primary groups, non-TIR- and TIRNBS-LRR, were obviously distinguished, which is consistent with previously described patterns $[9,15]$. The nonTIR-NBS-LRR subfamily included thirty-eight members (CaRGA13-CaRGA43, CaRGA45-CaRGA48, CaRGA51, BS2 and $C a M i)$, whereas only fifteen members (CaRGA01-CaRGA12, CaRGA49-CaRGA50 and CaRGA44) belonged to the TIR-NBS-LRR subfamily. These results support the view that both TIR-NBSLRR and non-TIR-NBS-LRR $\mathrm{R}$ genes occur in dicot species [15]. Within the non-TIR-NBS-LRR subfamily, CaRGAs could be separated into four subgroups, which were designated CaRGA I-IV. In the TIR-NBS-LRR subfamily, the CaRGAs could be divided into three subgroups, which were designated CaRGA V-VII. Each of these seven subgroups included different numbers of CaRGA members. The CaRGA III, CaRGA IV, CaRGA V and CaRGA VI subgroups contained two to four members, whereas the CaRGA I, CaRGA II and CaRGA VII subgroups consisted of eight to nineteen members. This result reflects a difference in the abundance of these RGA subgroups in the pepper genome (Figure 1). The characteristics of these non-TIR- and TIR-NBS CaRGA sequences from pepper are shown in Table 1.

We further revealed that sequence identity between the CaRGAs from PCR amplification and database mining ranged from 21.9\% (CaRGA III-V) to 64.9\% (CaRGA I and CaRGA II) at the amino acid level (Table 2). This finding indicates that these CaRGAs are characterized by a high degree of divergence. There were also different degrees of variation in sequence homology within each group. The highest value was observed for CaRGA25 and CaRGA20 (99.8\%) (CaRGA I) and the lowest value was observed for CaRGA17 and CaRGA51 (39.8\%) (CaRGA III). CaRGA25 and CaRGA20 may have evolved from a common ancestor gene and CaRGA17 and CaRGA51 may have convergent evolutionary origins. Compared with known $\mathrm{R}$ genes, the sequence identity ranged from $18.5 \%$ (between Gpa2 and CaRGA V) to 69.1\% (between $N$ and CaRGA VI) at the amino acid level (Table 2). We also analyzed sequence identity between the CaRGAs from PCR amplification and database mining and two $\mathrm{R}$ genes (Bs2 and $\mathrm{CaMi}$ ) reported. The highest value was observed for CaRGA13 and CaMi (80.7\%) and the lowest value was observed for CaRGA44 and CaMi (20.3\%). In addition, the BLASTP search of these seven subgroups revealed that their sequences had the highest degree of identity and similarity with known 


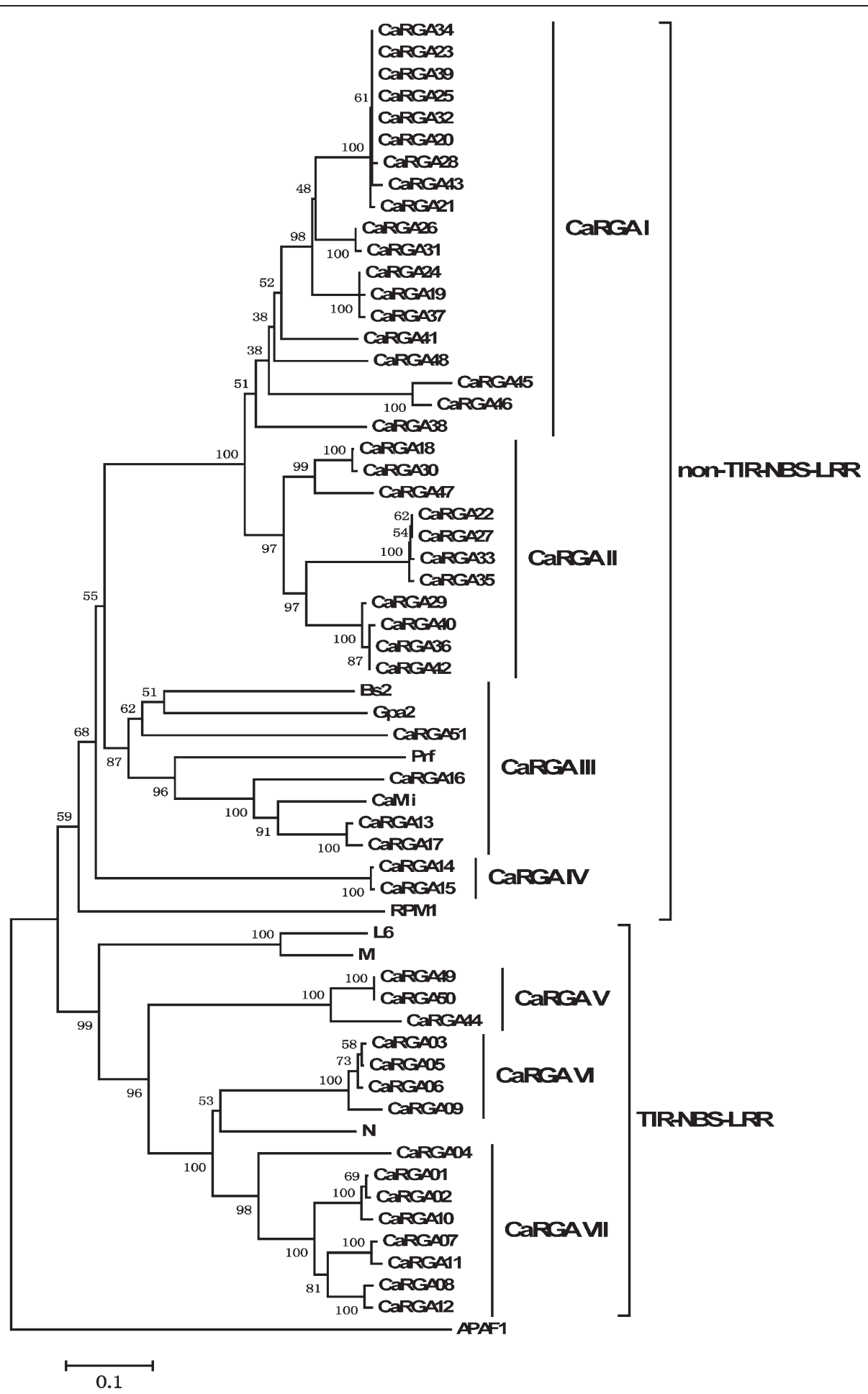

Figure 1 Phylogenetic tree analysis based on alignment of the deduced amino acid sequences of pepper CaRGAs with known R genes. The tree was constructed by the neighbor-joining method using MEGA 5.0 software. The 51 CaRGA sequences and 2 resistance genes were grouped into seven subgroups: I-VII. I-IV are part of the non-TIR-NBS-LRR family, whereas V-VII belong to the TIR-NBS-LRR family. Bootstrap values (1000 replicates) are given below the branches. The known R genes with the NBS domain that were used were N (U15605), L6 (U27081), M (U73916), Prf (U65391), Gpa2 (AF195939) and RPM1 (X87851). 
Table 1 Characteristics of non-TIR and TIR-NBS CaRGAs from pepper (Capsicum anuum L.)

\begin{tabular}{|c|c|c|c|c|}
\hline Non-TIR/TIR & Class & Clone name & $\begin{array}{l}\text { Length of encoding nucleotide } \\
\text { residues (bp) and amino acids (aa) }\end{array}$ & GenBank accession number \\
\hline \multirow[t]{4}{*}{ Non-TIR-NBS-LRR } & CaRGA I & $\begin{array}{l}\text { CaRGA23;CaRGA28;CaRGA34; } \\
\text { CaRGA43; CaRGA25;CaRGA39; } \\
\text { CaRGA32;CaRGA20; CaRGA21; } \\
\text { CaRGA26;CaRGA31;CaRGA24; } \\
\text { CaRGA19;CaRGA37;CaRGA48; } \\
\text { CaRGA41; CaRGA45; CaRGA46; } \\
\text { CaRGA38 }\end{array}$ & $\begin{array}{l}723 / 240 ; 722 / 240 ; 722 / 240 ; 706 / 234 \\
728 / 242 ; 701 / 233 ; 722 / 240 ; 697 / 232 \\
684 / 227 ; 728 / 242 ; 712 / 237 ; 731 / 243 \\
730 / 243 ; 731 / 243 ; 613 / 204 ; 703 / 234 \\
510 / 170 ; 608 / 202 ; 707 / 235\end{array}$ & $\begin{array}{l}\text { DQ205986;DQ205995; DQ206007; DQ206021; } \\
\text { DQ205988;DQ206016; DQ206000; DQ205982; } \\
\text { DQ205984;DQ205989; DQ205999; DQ205987; } \\
\text { DQ205981;DQ206010; FJ605106; DQ206019; } \\
\text { FJ605101; FJ605102; DQ206015 }\end{array}$ \\
\hline & CaRGA ॥ & $\begin{array}{l}\text { CaRGA18;CaRGA30;CaRGA47; } \\
\text { CaRGA22; CaRGA27;CaRGA33; } \\
\text { CaRGA35;CaRGA29; CaRGA36; } \\
\text { CaRGA40; CaRGA42 }\end{array}$ & $\begin{array}{l}704 / 234 ; 706 / 234 ; 628 / 209 ; 725 / 241 \\
709 / 236 ; 692 / 230 ; 714 / 238 ; 655 / 218 \\
725 / 241 ; 725 / 241 ; 725 / 241\end{array}$ & $\begin{array}{l}\text { DQ205980; DQ205998; FJ605103; DQ205985; } \\
\text { DQ205992; DQ206001;DQ206008; DQ205997; } \\
\text { DQ206009; DQ206018; DQ206020 }\end{array}$ \\
\hline & $\overline{\text { CaRGA III }}$ & $\begin{array}{l}\text { CaRGA51;CaRGA16;CaRGA13; } \\
\text { CaRGA17 Bs2; CaMi }\end{array}$ & $\begin{array}{l}\text { 525/175;513/171;501/167; 501/167 } \\
\text { 2715/905; 3774/1257 }\end{array}$ & $\begin{array}{l}\text { AF513548; JN112315; JN112312; JN112316 } \\
\text { AF202179; DQ465824 }\end{array}$ \\
\hline & CaRGA IV & CaRGA14; CaRGA15 & $516 / 172 ; 516 / 172$ & JN112313; JN112314 \\
\hline \multirow[t]{3}{*}{ TIR-NBS-LRR } & CaRGA V & CaRGA49; CaRGA50; CaRGA44 & 512/171;563/178; 492/161 & FJ605108; FJ605109; FJ605100 \\
\hline & CaRGA VI & $\begin{array}{l}\text { CaRGA03;CaRGA09;CaRGA05; } \\
\text { CaRGA06 }\end{array}$ & $495 / 165 ; 456 / 152 ; 495 / 165 ; 495 / 165$ & JN112302; JN112308; JN112304; JN112305 \\
\hline & CaRGA VII & $\begin{array}{l}\text { CaRGA04;CaRGA02;CaRGA10; } \\
\text { CaRGA01; CaRGA07;CaRGA11; } \\
\text { CaRGA08; CaRGA12 }\end{array}$ & $\begin{array}{l}513 / 171 ; 504 / 168 ; 504 / 168 ; 504 / 168 \\
504 / 168 ; 504 / 168 ; 504 / 168 ; 504 / 168\end{array}$ & $\begin{array}{l}\text { JN1 12303;JN112301;JN1 12309;JN1 12300; } \\
\text { JN112306; JN112310; JN112307; JN112311 }\end{array}$ \\
\hline
\end{tabular}

R genes or RGAs from Solanaceae crops. CaRGAs I and II showed the highest degree of similarity with the R3a-like disease-resistance protein gene from Solanum demissum. The sequences of CaRGAs III and VII were most similar to Mi-1.4 from Solanum sp. VFNT and bacterial spot disease-resistance protein genes (Bs4) from S. lycopersicum, respectively. The remaining CaRGAs IV, V and VI were most similar to the NBS-encoding resistance protein genes from S. aculeatissimum, S. circaeifolium and S. lycopersicum, respectively (Table 3 ).

Table 2 Amino acid sequence similarity (\%) among representatives of the seven CaRGA subgroups identified from pepper and six known NBS-LRR plant $R$ genes

\begin{tabular}{|c|c|c|c|c|c|c|c|c|c|c|c|c|c|c|c|}
\hline Name & CaRGA I & CaRGA II & CaRGA III & CaRGA IV & CaRGA V & CaRGA VI & CaRGA VII & RPM1 & Gpa2 & L6 & $M$ & $N$ & Prf & Bs2 & CaM \\
\hline $\begin{array}{l}\text { CaRGA I } \\
\text { (CaRGA23) }\end{array}$ & 100 & & & & & & & & & & & & & & \\
\hline $\begin{array}{l}\text { CaRGA II } \\
\text { (CaRGA33) }\end{array}$ & 64.9 & 100 & & & & & & & & & & & & & \\
\hline $\begin{array}{l}\text { CaRGA III } \\
\text { (CaRGA13) }\end{array}$ & 40.6 & 39.4 & 100 & & & & & & & & & & & & \\
\hline $\begin{array}{l}\text { CaRGA IV } \\
\text { (CaRGA14) }\end{array}$ & 36.3 & 33.9 & 38.2 & 100 & & & & & & & & & & & \\
\hline $\begin{array}{l}\text { CaRGA V } \\
\text { (CaRGA44) }\end{array}$ & 22.2 & 22.2 & 21.9 & 23.0 & 100 & & & & & & & & & & \\
\hline $\begin{array}{l}\text { CaRGA VI } \\
\text { (CaRGA05) }\end{array}$ & 27.5 & 28.8 & 26.8 & 24.7 & 43.9 & 100 & & & & & & & & & \\
\hline $\begin{array}{l}\text { CaRGA VII } \\
\text { (CaRGA01) }\end{array}$ & 27.3 & 29.8 & 23.4 & 25.8 & 47.5 & 61.2 & 100 & & & & & & & & \\
\hline$\overline{R P M 1}$ & 29.9 & 31.1 & 33.3 & 33.9 & 21.7 & 24.4 & 24.5 & 100 & & & & & & & \\
\hline Gpa2 & 39.4 & 36.3 & 47.8 & 31.5 & 18.5 & 23.8 & 23.0 & 31.7 & 100 & & & & & & \\
\hline$\overline{L 6}$ & 29.2 & 29.2 & 26.7 & 22.8 & 38.6 & 35.8 & 33.3 & 22.0 & 25.0 & 100 & & & & & \\
\hline $\bar{M}$ & 29.2 & 29.8 & 28.0 & 25.3 & 40.9 & 35.0 & 34.3 & 24.6 & 28.8 & 81.8 & 100 & & & & \\
\hline $\bar{N}$ & 28.8 & 31.3 & 28.1 & 26.7 & 49.0 & 69.1 & 66.1 & 24.5 & 26.0 & 37.7 & 35.6 & 100 & & & \\
\hline$\overline{\text { Prf }}$ & 33.3 & 33.3 & 53.0 & 34.5 & 18.4 & 23.6 & 21.5 & 26.5 & 47.2 & 23.5 & 24.1 & 25.0 & 100 & & \\
\hline Bs2 & 38.5 & 34.8 & 42.3 & 32.7 & 27.0 & 27.3 & 26.9 & 28.9 & 51.9 & 26.2 & 27.5 & 26.1 & 40.5 & 100 & \\
\hline CaMi & 45.3 & 47.2 & 80.7 & 37.2 & 20.3 & 23.9 & 24.4 & 31.5 & 42.9 & 21.9 & 22.8 & 28.0 & 50.0 & 40.5 & 100 \\
\hline
\end{tabular}

The analysis was carried out with sequences spanning the P-loop and GLPL motifs. 
Table 3 Sequence homology comparisons between representatives of the identified pepper CaRGAs subgroups and its closest homolog in the GenBank

\begin{tabular}{|c|c|c|c|c|c|c|c|}
\hline Pepper RGAs* & $\begin{array}{c}\text { GenBank } \\
\text { accessions }\end{array}$ & Plant species & Similar to & $\begin{array}{l}\text { Length of BLASTX } \\
\text { alignment }\end{array}$ & $\begin{array}{l}\text { Identity } \\
(\%)\end{array}$ & $\begin{array}{l}\text { Similarity } \\
(\%)\end{array}$ & E-value \\
\hline$\overline{\text { CaRGA I (CaRGA23) }}$ & EF613519 & Solanum demissum & $\begin{array}{l}\text { R3a-like disease resistance } \\
\text { protein gene }\end{array}$ & 171 & 82 & 93 & $1 e-64$ \\
\hline$\overline{C a R G A} \|(C a R G A 33)$ & EF613542 & Solanum demissum & $\begin{array}{l}\text { R3a-like disease resistance } \\
\text { protein gene }\end{array}$ & 171 & 77 & 87 & $5 e-72$ \\
\hline$\overline{C a R G A}$ III (CaRGA13) & DQ863287 & Solanum sp. VFNT & $\begin{array}{l}\text { Mi-1.4 disease resistance } \\
\text { protein gene }\end{array}$ & 166 & 83 & 91 & $4 \mathrm{e}-64$ \\
\hline$\overline{\text { CaRGA IV (CaRGA14) }}$ & GU199034 & Solanum aculeatissimum & $\begin{array}{l}\text { NBS-encoding resistance } \\
\text { protein gene (RGA8) }\end{array}$ & 171 & 88 & 94 & $4 \mathrm{e}-85$ \\
\hline$\overline{C a R G A ~ \vee ~(C a R G A 44) ~}$ & Y16680 & Solanum circaeifolium & $\begin{array}{l}\text { NBS-encoding resistance } \\
\text { protein gene (clone crc Rgen8) }\end{array}$ & 161 & 68 & 79 & $2 e-39$ \\
\hline CaRGA VI (CaRGA05) & AF404422 & Solanum Lycopersicon & $\begin{array}{l}\text { Nucleotide binding region of } \\
\text { resistance-like gene }(\mathrm{Q} 8)\end{array}$ & 165 & 84 & 90 & $3 e-76$ \\
\hline$\overline{\text { CaRGA VII (CaRGA01) }}$ & AY438027 & Solanum Lycopersicon & $\begin{array}{l}\text { Bacterial spot disease } \\
\text { resistance protein gene (Bs4) }\end{array}$ & 168 & 78 & 90 & $2 e-65$ \\
\hline
\end{tabular}

*RGA I to RGA VII represent seven classes of the pepper CaRGAs, respectively.

\section{Multiple sequence alignments of non-TIR- and TIR-NBS-LRR RGAs in pepper}

The CaRGAs identified from pepper were obviously separated into non-TIR- and TIR-NBS-LRR subfamilies (Figure 1). Consequently, multiple sequence alignments of non-TIR- and TIR-NBS-LRR RGAs were performed separately. The sequence alignment between non-TIRNBS-LRR RGAs and known disease $\mathrm{R}$ genes, including RPM1, Gpa2 and Prf, revealed six conserved motifs (i.e. P-loop, RNBS-A-non-TIR, kinase-2, RNBS-B, RNBS-C and GLPL) (Figure 2). Similarly, alignment analysis with known $\mathrm{R}$ genes $N, M$ and $L 6$ revealed that the TIR-NBSLRR RGAs also contain six conserved motifs (i.e. P-loop, RNBS-A-TIR, kinase-2, RNBS-B, RNBS-C and GLPL) (Figure 3). The presence of these consensus motifs within the non-TIR- and TIR-NBS-LRR CaRGAs provides further evidence that the cloned sequences are NBS-LRR gene family members.

\section{Analysis of functional divergence between the non-TIR- and TIR-NBS-LRR CaRGA subfamilies}

Type I and II functional divergence between the nonTIR- and TIR-NBS-LRR subfamilies of pepper was assessed by posterior analysis using DIVERGE 2.0 software, which evaluates the (site-specific) shifted evolutionary rate after gene duplication or speciation $[44,45]$. Posterior analysis results in a site-specific profile for predicting important amino acid residues responsible for functional divergence. The estimation was based on multiple sequence alignments and a neighbor-joining (NJ) tree of the NBS domain of the pepper RGAs, with clear separation of the two different subfamilies, nonTIR- and TIR-NBS-LRR (Figure 1). The coefficient of type-I functional divergence $\left(\theta_{I}\right)$ between the non-TIRand TIR-NBS-LRR subfamilies was significantly greater than $0\left(\theta_{\mathrm{I}}=0.533 \pm 0.156, P<0.05\right)$. This result suggests that the altered functional constraint between the subfamilies is statistically significant and that some amino acid sites are subjected to different site-specific shifts in evolutionary rate that can lead to a subfamily-specific functional evolution after diversification. Compared with the findings for type-I functional divergence, the coefficient of type-II functional divergence $\left(\theta_{\text {II }}\right)$ between the non-TIR- and TIR-NBS-LRR subfamilies was less than 0 . Therefore, type-I functional divergence was the primary pattern for the evolution of the non-TIR- and TIR-NBSLRR subfamilies in pepper.

We further estimated the critical amino acid residues responsible for the functional divergence by calculating the site-specific profile based on a posterior probability $\left(Q_{k}\right)$ analysis of the non-TIR- and TIR-NBS-LRR subfamilies. Among all of the aligned sites, the $Q_{k}$ values of most sites were $<0.5$ (Additional file 3 ). To reduce false positives, $Q_{k}>0.70$ was used as a cut-off to identify critical amino acid residues associated with type-I functional divergence between the non-TIR- and TIR-NBS-LRR subfamilies. A total of thirteen sites (positions 21, 22, 23, 69, 84, 104, 113, 116, 118, 125, 146, 155 and 165) were predicted (Additional file 3). Among these sites, the $Q_{k}$ value of site 22 was 0.878 , which was predicted to be highly related to functional divergence, whereas the degree of relation to functional divergence was lowest at site $155\left(Q_{k}=0.729\right)$.

We also found that the degree of conservation of critical amino acid residues differed between non-TIR- and TIR-NBS-LRR RGAs. For example, the amino acid residue at site 22 was valine (V) and leucine (L) in the non-TIR- and TIR-NBS-LRR RGAs, respectively. Nevertheless, some amino acid residues were highly conserved between the subfamilies, such as those at sites 84 (E), 


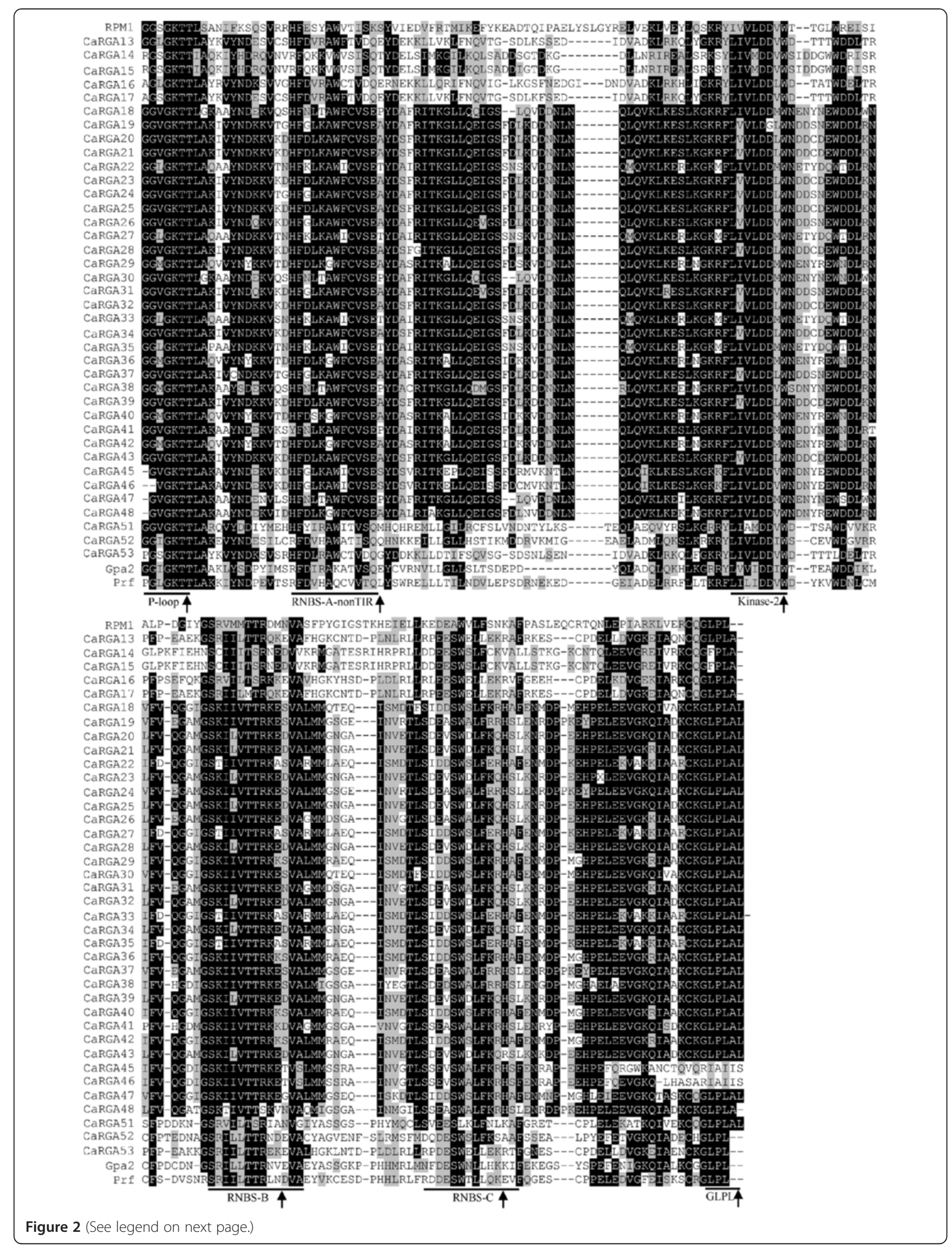


(See figure on previous page.)

Figure 2 Amino acid sequence alignment between P-loop and GLPL of non-TIR-NBS-LRR CaRGAs with the NBS domains of known R genes Prf (U65391), Gpa2 (AF195939) and RPM1 (X87851). Conserved domains are highlighted and indicated by an arrow. The alignment was constructed using BioEdit 7.0.0 software. The threshold (\%) for shading was set at 50 . Similar amino acid residues are shaded grey and identical amino acid residues are shaded black.

133 (F) and 155 (W) from the non-TIR-NBS-LRR subfamily and sites 23 (S), $116(\mathrm{~W}), 118(\mathrm{G})$ and 146 (V) from the TIR-NBS-LRR subfamily (Figure 4). These results suggest that these critical amino acid residue sites are subjected to strong functional constraints within the non-TIR- and TIR-NBS-LRR subfamilies.

\section{Comparing evolutionary rates among NBS-LRR RGAs in pepper}

The evolutionary rates were compared within the nonTIR- and TIR-NBS-LRR subfamilies. The $\mathrm{Ka} / \mathrm{Ks}$ ratio is an indicator for comparing evolutionary rates in $R$ genes [46]. Generally, a $\mathrm{Ka} / \mathrm{Ks}$ ratio $>1$ implies positive or diversifying selection (i.e. advantageous mutations have been accumulated during the course of evolution); a $\mathrm{Ka} / \mathrm{Ks}$ ratio $<1$ indicates a purifying or negative selection (i.e. most of the non-synonymous substitutions have been eliminated); and a $\mathrm{Ka} / \mathrm{Ks}$ ratio $=1$ indicates neutral selection [47]. In the current paper, we found that within the non-TIR-NBS-LRR subfamily, most $\mathrm{Ka} /$ Ks values were $<1$ in pairwise comparisons, with the exception of CaRGA III/CaRGAIV. This finding suggests that these gene pairs may be under purifying selection. However, CaRGA III/CaRGA IV was under positive selection. Within the TIR-NBS-LRR subfamily, all the $\mathrm{Ka} / \mathrm{Ks}$ values were $<1$, indicating that both subfamilies were under strong selective constraints (Table 4). Purifying selection could play a critical role in the evolutionary processes of non-TIR- and TIRNBS-LRR RGAs in pepper.

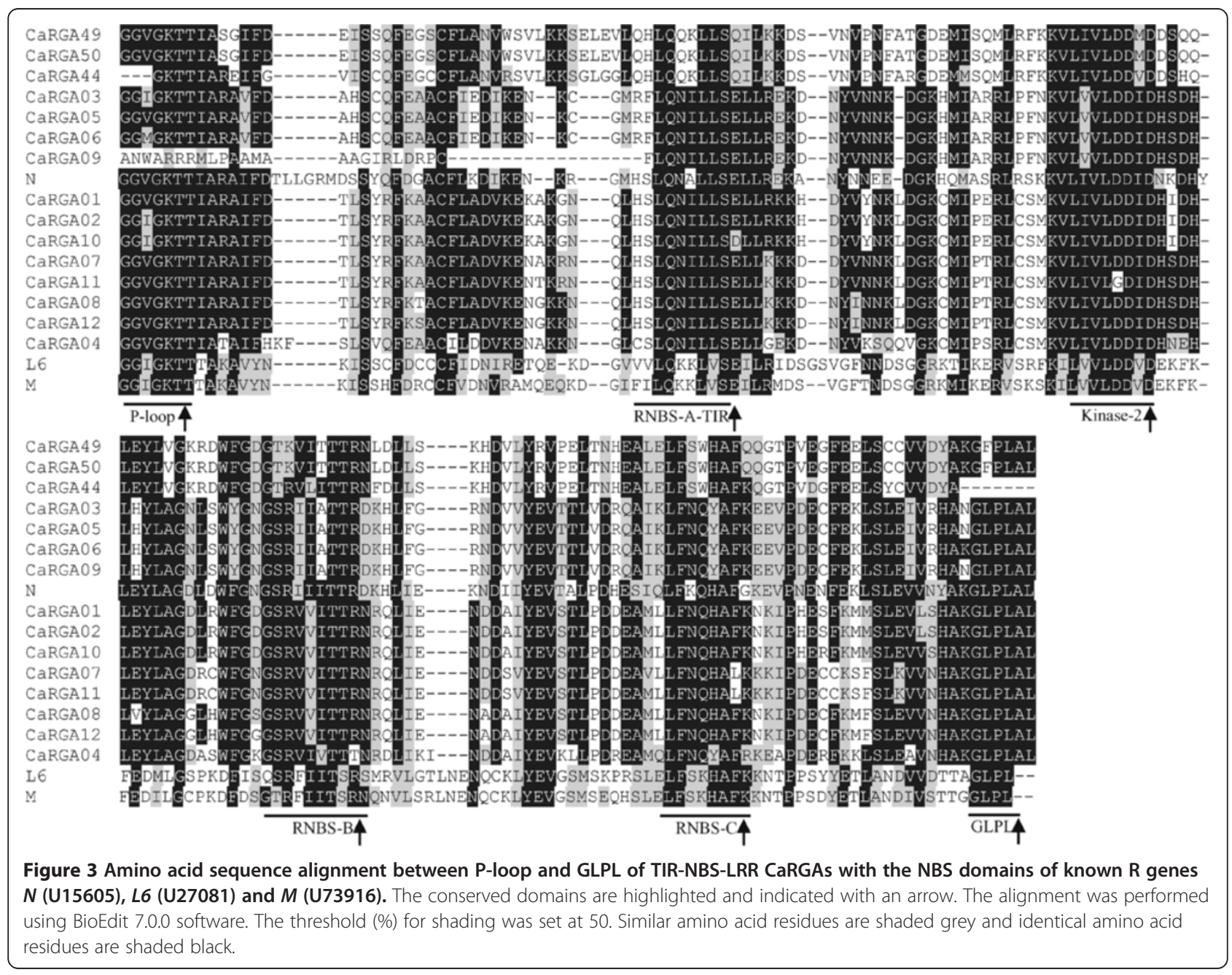




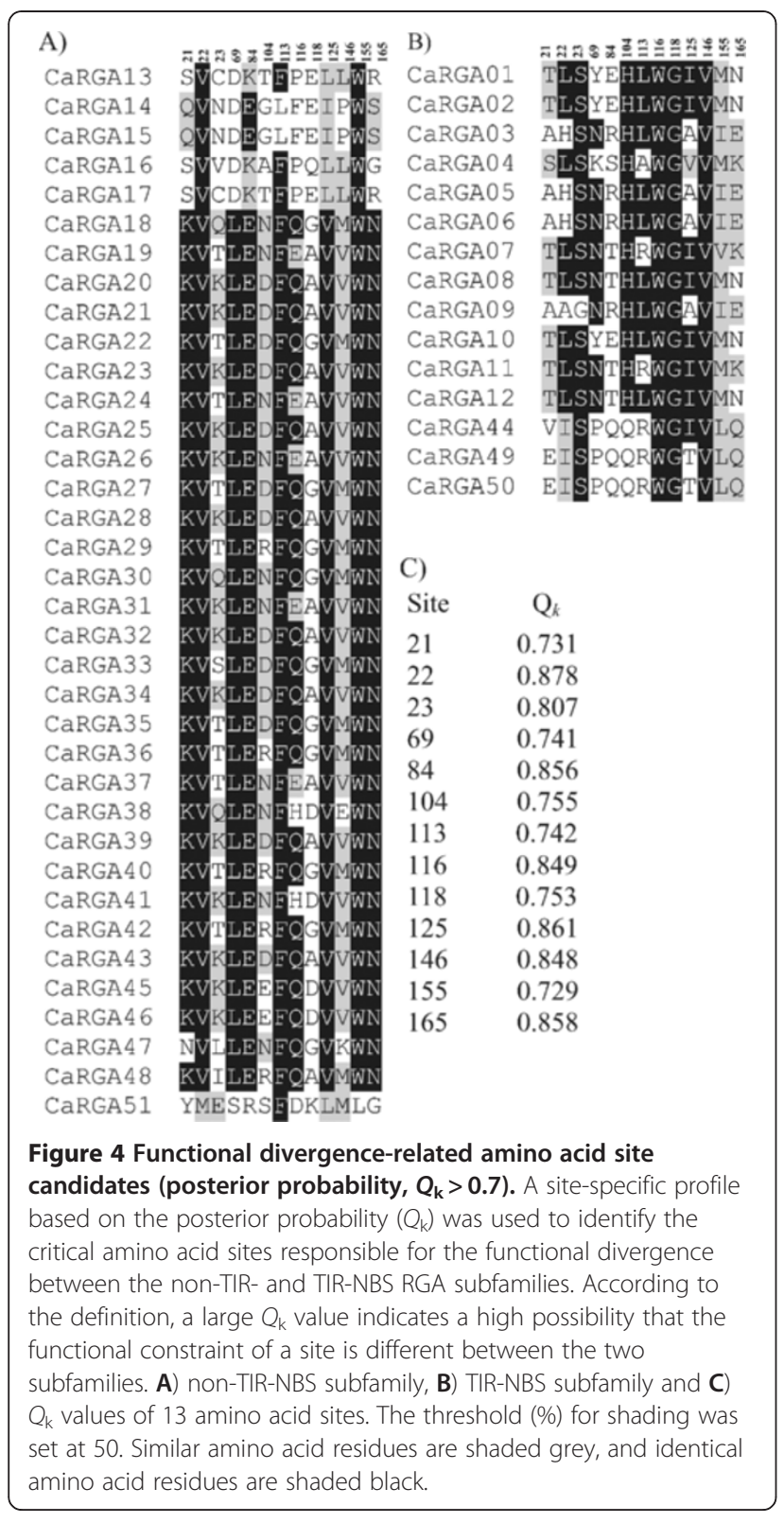

\section{Sliding window analysis}

A sliding window analysis of the $\mathrm{Ka} / \mathrm{Ks}$ ratios was carried out alongside the determination of the nucleotide sequences of the RGAs for pairwise comparison of any two groups using CRANN software to explore important regions that may have contributed to the functional diversification of NBS-LRR RGAs in pepper [48]. Within the non-TIR-NBS-LRR subfamily, we observed two groups of pairwise comparisons that showed similar tendencies. One was CaRGA I/CaRGA IV and CaRGA II/ CaRGA IV, the other was CaRGA II/CaRGA III and CaRGA III/CaRGA IV. The remaining two groups showed different patterns. Overall, the sliding window profile revealed at least three regions of high peaks that
Table $4 \mathrm{Ka} / \mathrm{Ks}$ ratios for pairwise comparisons among members of the non-TIR and TIR-NBS CaRGA subfamilies in pepper

\begin{tabular}{llccc}
\hline Group & Pairwise comparison & Ka & Ks & Ka/Ks \\
\hline Non-TIR-NBS & CaRGA I/CaRGA II & 0.218 & 0.370 & 0.589 \\
\cline { 2 - 5 } & CaRGA I/CaRGA III & 0.571 & 0.772 & 0.740 \\
\cline { 2 - 5 } & CaRGA I/CaRGA IV & 0.674 & 0.798 & 0.845 \\
\cline { 2 - 5 } & CaRGA II/CaRGA III & 0.612 & 0.735 & 0.833 \\
\cline { 2 - 5 } & CaRGA II/CaRGA IV & 0.767 & 2.441 & 0.314 \\
\cline { 2 - 5 } & CaRGA III/CaRGA IV & 0.656 & 0.607 & 1.081 \\
\hline TIR-NBS & CaRGA V/CaRGA VI & 0.479 & 0.823 & 0.582 \\
\cline { 2 - 5 } & CaRGA V/CaRGA VII & 0.462 & 1.271 & 0.363 \\
\cline { 2 - 5 } & CaRGA VI/CaRGA VII & 0.274 & 0.718 & 0.382 \\
\hline
\end{tabular}

were under positive selection, given that all $\mathrm{Ka} / \mathrm{Ks}$ values were $>1$ (Figure 5A). Within the TIR-NBS-LRR subfamily, we observed 2-3 regions of high peaks with high $\mathrm{Ka} /$ Ks values, consistent with positive selection in three pairwise comparisons (Figure 5B). These regions may be exposed to strong functional constraints. Two of these regions may be located in the RNBS-B and RNBS-C domains, respectively. Therefore, we inferred that the observed difference in the regions of functional constraint may reflect the functional specificities of NBSLRR RGAs in pepper.

\section{Determination of functional specificity positions among pepper NBS-LRR RGAs}

In plants, many protein families contain homologous proteins that have common biological functions but different specificities towards substrates, ligands, effectors, DNA, proteins and other interacting molecules, including other monomers of the same protein. All these interactions must be highly specific [49]. Thus, important amino acid residues that account for the functional specificity of proteins from a family need to be identified. These important amino acid residue positions are well conserved within specificity groups but differ between different functional subgroups. Such positions are called SDPs (specificity-determining positions) [49]. The SDPfox server was used to predict potential SDPs and identify amino acid residues that are remarkably responsible for the functional specificity of the non-TIR- and TIR-NBS-LRR RGAs of pepper (Table 5 and Additional file 4). Four SDPs (positions 91, 98, 146 and 124) were predicted to be involved in functional specificity. Further analysis revealed that position 98 was located between the kinase- 2 and RNBS-B domains. However, currently, there is no function associated with this region. The remaining three SPDs were located in three different conserved domains (i.e. kinase-2, RNBS-B and RNBS-C). 
A)

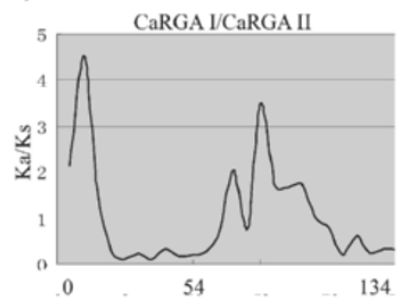

CaRGA II/CaRGA III

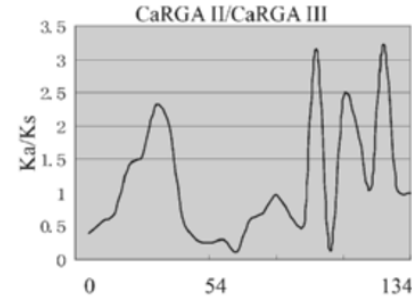

B)

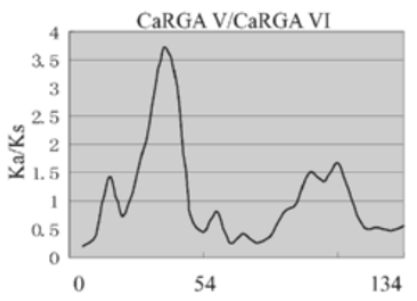

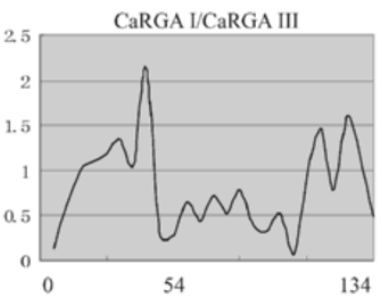
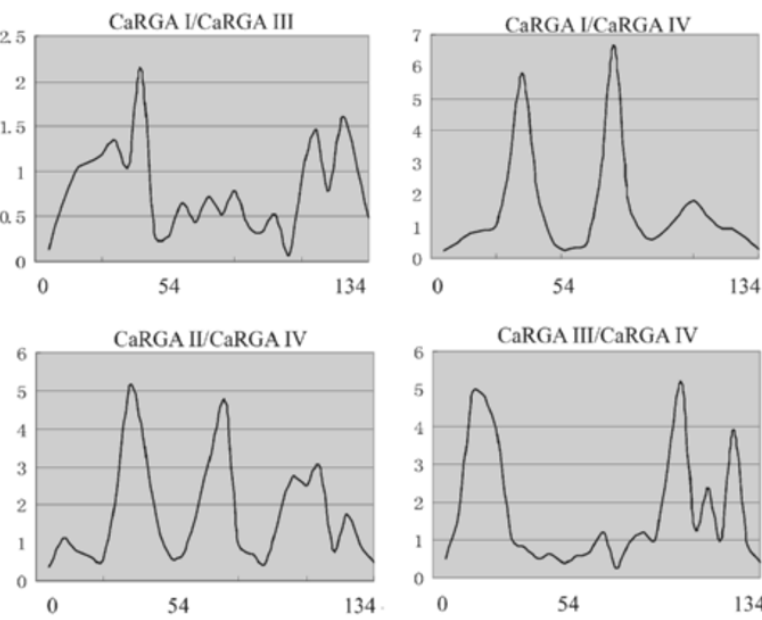

CaRGA III/CaRGA IV

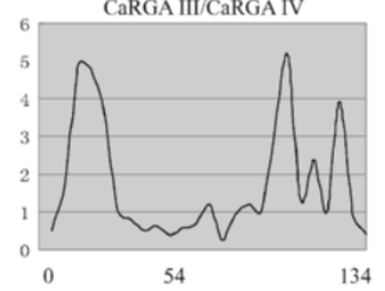

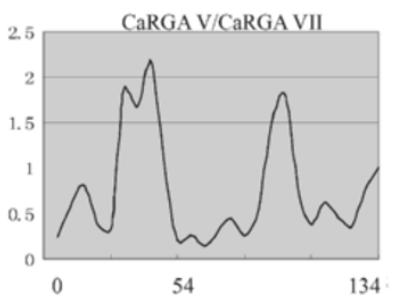

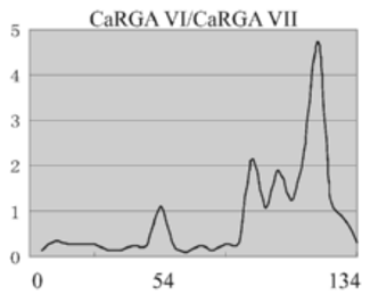

Figure 5 Sliding window analyses of $\mathrm{Ka} / \mathrm{Ks}$ ratios for any two groups in the non-TIR- and TIR-NBS subfamilies. The Y-axis shows the $\mathrm{Ka} / \mathrm{Ks}$ ratio, and the $\mathrm{X}$-axis shows the amino acid numbers of the aligned sequences.

Expression analysis of CaRGAs in different organs and in response to defence signaling molecules

To analyze the expression levels of CaRGAs in the different organs of pepper, two representatives of each class were randomly used for expression analysis using reverse transcription (RT)-PCR. CaRGA14 and CaRGA15 were the only two members of Class CaRGAIV. Given that the sequence similarity among these RGAs was high, only one pair of specific primers was designed using Primer 5.0 software. A total of thirteen pairs of specific primers were obtained. As shown in Figure 6A, thirteen CaRGAs were expressed in different plant organs, but their expression

Table 5 Predicted specificity-determining residues of the non-TIR and TIR-NBS-LRR RGAs subfamilies in pepper

\begin{tabular}{lcccccc}
\hline & Alignment position* & \multicolumn{2}{l}{ R gene group } & Z-score & P-value \\
\cline { 2 - 5 } & & Non-TIR & TIR & & \\
\hline 1 & 91 & W & D & 4.72 & $2.41 \times 10^{-4}$ \\
\hline 2 & 98 & W & Y & 4.71 & $2.83 \times 10^{-8}$ \\
\hline 3 & 146 & S & A & 4.68 & $3.49 \times 10^{-12}$ \\
\hline 4 & 124 & V & L & 4.67 & $3.01 \times 10^{-16}$
\end{tabular}

*Alignment position designates the amino acid position in the multiple sequence alignment presented in Additional file 3.

**P-value was used to evaluate the significance of the Z-score and assess whether the observed Z-score is sufficiently high to indicate an SDP. levels were different. Among these, CaRGA04, CaRGA13 and CaRGA38 were expressed in the leaves, stems and roots at low levels, whereas CaRGA01, CaRGA03, CaRGA14 and CaRGA18 were expressed at relatively high levels. The remaining CaRGAs were expressed at intermediate levels. No expression of CaRGA44 and CaRGA49 genes was detected in the roots. The CaRGAV and II subgroups showed similar expression patterns.

After treatment with abscisic acid (ABA) and salicylic acid (SA), the expression levels of most of these CaRGA genes changed. We found that the addition of ABA increased the transcription levels of several of the analysed CaRGA genes, namely CaRGA18, CaRGA51, CaRGA23, CaRGA14 and CaRGA49. By contrast, ABA addition decreased the expression levels of CaRGA13, CaRGA01 and CaRGA05. However, the expression of CaRGA03, CaRGA36 and CaRGA38 were unchanged. $\mathrm{SA}$ is known to play a vital role in plant defence against pathogens [50]. SA also induces the expression of a range of pathogen defence genes in plants [51,52]. Among the CaRGAs tested, CaRGA01, CaRGA05, CaRGA03, CaRGA49, CaRGA14, CaRGA51, CaRGA36 and CaRGA38 displayed the most marked responses to SA treatment (Figure 6A). The expression levels of CaRGA18 and CaRGA23 decreased. The remaining 


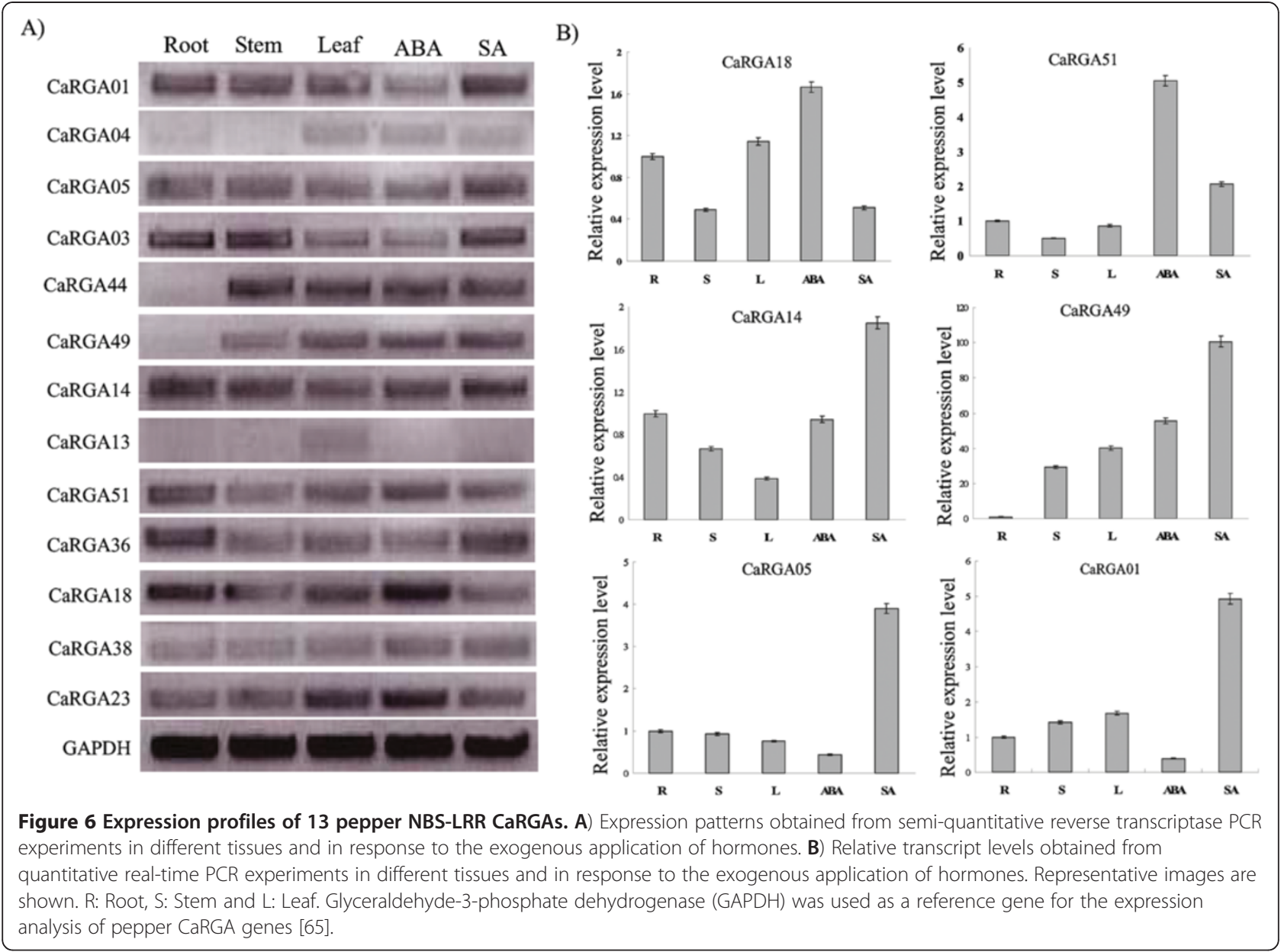

genes showed no response to the SA treatment conditions. Real time-PCR experiments confirmed the expression levels of the selected CaRGAs (Figure 6B).

We found that two members from a subgroup may have different expression patterns, such as CaRGA01 and CaRGA04. However, similar expression patterns were also observed (CaRGA44 and CaRGA49). We also found that the CaRGAIV and VI subgroups had similar expression patterns. However, whether these genes with similar expression patterns have similar functions remains unclear. In addition, some earlier studies have reported that signaling molecules not only function as a critical signal for downstream resistance events but also upregulate the expression of $\mathrm{R}$ genes [51-56]. Some CaRGA genes were activated by SA and ABA (Figures $6 \mathrm{~A}$ and $6 \mathrm{~B}$ ). This suggests that these stimuli induce the expression of the CaRGA genes and that they may play a potential role in mediating cross-talk between signaling pathways.

In summary, this paper provided detailed characterization and data on the functional divergence of nonTIR- and TIR-NBS-LRR CaRGAs in pepper. The mode of selection (positive selection, purifying selection and neutral selection) among the non-TIR- and TIR-NBS-LRR
CaRGA subfamilies was identified by $\mathrm{Ka} / \mathrm{Ks}$ analysis. However, the kind of evolutionary mechanisms responsible for the evolution of $\mathrm{R}$ genes in pepper cannot be inferred with certainty without the complete set of NBS-LRR genes from the pepper genome. Future studies must focus on verifying and elucidating the biological function of these CaRGA genes using supplementary experimental approaches, particularly with virus- or Agrobacterium-mediated transient assays [57] or by performing loss-of-function experiments, such as virus-induced gene silencing [58].

\section{Conclusion}

The present study identified numerous CaRGA sequences through degenerate PCR amplification and database mining. We divided these CaRGA sequences into two subfamilies (non-TIR- and TIR-NBS-LRR) based on phylogenetic tree and sequence analyses. The identified CaRGAs are a valuable resource for discovering $\mathrm{R}$ genes and developing RGA molecular markers that can be used for genetic mapping in pepper. We also predicted thirteen sites (positions 21, 22, 23, 69, 84, 104, $113,116,118,125,146,155$ and 165) as critical amino acid residues associated with the type-I functional 
divergence between non-TIR- and TIR-NBS-LRR subfamilies. Ka and Ks analyses showed that a purifying selection could play a critical role in the evolutionary processes of non-TIR- and TIR-NBS-LRR CaRGAs in pepper.

In addition, four SDPs (positions 91, 98, 146 and 124) were predicted to be involved in functional specificity in the non-TIR- and TIR-NBS-LRR CaRGA subfamilies. Expression analysis showed that some CaRGA genes were induced by $\mathrm{SA}$ or $\mathrm{ABA}$, suggesting that they may be mainly involved in defence responses activated by signaling pathways associated with these two molecules. These findings provide a better understanding of the evolutionary mechanisms driving the functional diversification of non-TIR- and TIR-NBS-LRR R genes in pepper.

\section{Methods}

Plant material

The sweet pepper breeding line PBC631B was selected to isolate potential NBS-type disease R genes. PBC631B seeds were germinated, and the seedlings were grown in growth chambers at $25^{\circ} \mathrm{C}$ for $12 \mathrm{~h}$ (day) and $18^{\circ} \mathrm{C}$ for $12 \mathrm{~h}$ (night). Relative humidity was maintained at 65$75 \%$. Young leaves were harvested from 4 week-old plants, immediately frozen in liquid nitrogen and then stored at $-80^{\circ} \mathrm{C}$ for nucleic acid extraction. For hormone treatments, the seedlings were cultured in Hoagland's solution containing $100 \mu \mathrm{M}$ SA and $100 \mu \mathrm{M}$ ABA for $6 \mathrm{~h}$. The treated samples were then harvested for testing. Genomic DNA was isolated using a commercial plant DNA extraction kit (Bioteke, Beijing, China) according to the manufacturer's instructions.

\section{Degenerate primers and PCR amplification}

Two pairs of degenerate primers were selected for isolating the RGA sequences in pepper (Additional file 5). The positions of the degenerate primers were identified in the two conserved domains (P-loop and GLPL, respectively) in the plant $R$ genes (Figure 7). PCR amplifications were performed using a PTC-100 thermal cycler. PCR amplification reactions were conducted in a total volume of $25 \mu \mathrm{L}$ containing $20 \mathrm{ng}$ of template DNA, $2 \mu \mathrm{L}$ of $10 \times$ PCR Buffer, $1.5 \mu \mathrm{L}$ of $25 \mathrm{mmol}$ $\mathrm{MgCl}_{2}, 2 \mu \mathrm{L}$ of dNTPs $(2 \mathrm{mmol} / \mathrm{L}), 1 \mu \mathrm{L}$ of Primer-F $(10 \mu \mathrm{mol} / \mathrm{L}), 1 \mu \mathrm{L}$ of Primer-R $(10 \mu \mathrm{mol} / \mathrm{L}), 1$ unit of ExTaq DNA $(5 \mathrm{U} / \mu \mathrm{L})$ and $15.3 \mu \mathrm{L}$ of $\mathrm{ddH}_{2} \mathrm{O}$. The PCR reaction cycle was as follows: denaturation at $94^{\circ} \mathrm{C}$ for $4 \mathrm{~min}$, followed by 35 cycles of denaturation at $94^{\circ} \mathrm{C}$ for $30 \mathrm{~s}$, annealing at $55^{\circ} \mathrm{C}$ for $30 \mathrm{~s}$ and extension at $72^{\circ} \mathrm{C}$ for $60 \mathrm{~s}$, followed by a final extension at $72^{\circ} \mathrm{C}$ for $5 \mathrm{~min}$.

\section{Cloning and sequencing of PCR products}

Full volumes of the PCR products were run on a $1.0 \%$ agarose gel. Bands of the expected size ( $\sim 500 \mathrm{bp})$ were excised from the agarose gel and purified using a DNA gel purification kit (Sangon, Shanghai, China). The obtained DNA was cloned into a pGEM T-Easy vector (Promega, Madison, WI, USA) and transformed into competent Escherichia coli JM $10^{9}$ cells according to the manufacturer's instructions. The cloned DNA fragment was sequenced by Bio-Asia Company (China).

\section{Collection of other NBS-LRR RGAs through database mining}

Other NBS-LRR RGAs from pepper were identified in the NCBI non-redundant protein database (http://www.ncbi. nlm.nih.gov/) using the key word 'Capsicum resistance genes'. A total of 54 NBS-LRR-type sequences were identified. Six known disease $\mathrm{R}$ genes, including $R P M 1$ (X87851), Gpa2 (AF195939), L6 (U27081), M (U73916), $N$ (U15605) and $\operatorname{Prf}$ (U65391) were downloaded from the GenBank database, and their phylogenetic relationship with pepper NBS-LRR disease R genes was determined.

\section{Sequence analysis and phylogenetic tree construction}

Each of the acquired DNA sequences was trimmed of vector sequence contamination using VecScreen at NCBI. Identity and similarity searches of nucleotide and

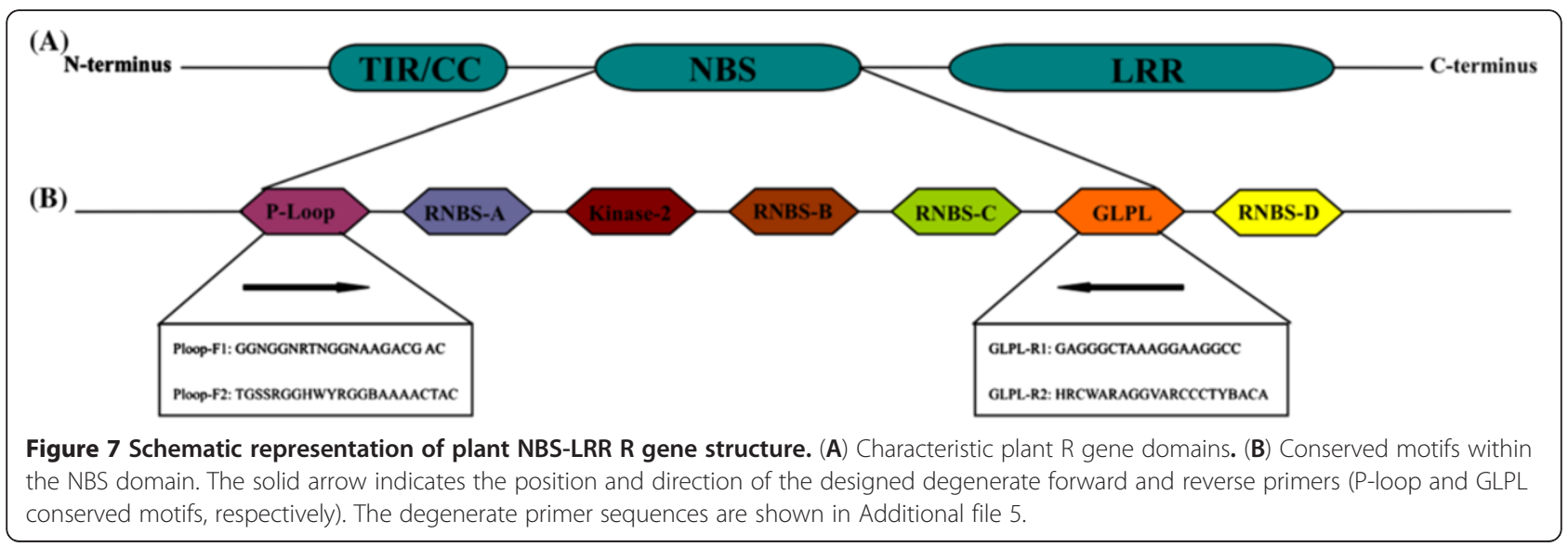


amino acid sequences were performed using BLAST at the NCBI GenBank database (http://www.ncbi.nlm.nih. gov/BLAST/). Sequence alignments were carried out using Clustal W (BioEdit software) [59]. The phylogenetic tree was constructed by the NJ method using MEGA 5.0 software [43]. The reliability of the interior nodes was assessed using 1000 bootstrap replicates. Human apoptosis activating factor-1 (Apaf-1), which contains homologous motifs with the NBS region in plant disease resistance genes, was included in the phylogenetic analysis as an outgroup sequence [60].

\section{Analysis of functional divergence}

The phylogenetic tree of the pepper NBS-LRR RGAs was broadly grouped into two clusters, namely the TIRand non-TIR-NBS-LRR subfamilies. DIVERGE 2 software [61] was used to evaluate the potential functional divergence and to predict the important amino acid residues in these two subfamilies. The coefficients of type I and II functional divergence $\left(\theta_{\mathrm{I}}\right.$ and $\left.\theta_{\mathrm{II}}\right)$ between these two groups of pepper NBS-LRR RGAs were estimated through posterior analysis. A $\theta_{\mathrm{I}}$ or $\theta_{\mathrm{II}}$ value significantly $>1$ indicates altered selective constraints or a radical shift in amino acid physiochemical properties after gene duplication and/or speciation [44,45]. A site-specific posterior analysis $\left(Q_{k}\right)$ was also used to predict amino acid residues important for functional divergence.

\section{Calculation of $\mathrm{Ka} / \mathrm{Ks}$ ratios}

We detected the mode of selection (positive selection, purifying selection or neutral selection) among the nonTIR- and TIR-NBS-LRR RGA subfamilies. The $\mathrm{Ka} / \mathrm{Ks}$ ratios were calculated according to Nei and Gojobori [62] using K-Estimator 6.0 software [63,64]. We identified the NBS-LRR RGAs subject to different selection pressures. DnaSP 5.0 software [65], which can calculate pairwise distance as part of a sliding window analysis, was applied. $\mathrm{Ka} / \mathrm{Ks}$ values were plotted using Microsoft Excel to produce a graph of $\mathrm{Ka}$ and $\mathrm{Ks}$ values. The resultant $\mathrm{Ka}$ and $\mathrm{Ks}$ values were the sum of every possible pairwise comparison between every subgroup of $\mathrm{R}$ gene candidates selected for that particular window.

\section{Analysis of SDPs}

SDPfox was used to predict the SDPs that may determine the functional specificity of homologous proteins [49]. SDP presents the statistical significance of the predictions in the form of Z-scores (the number of standard deviations away from the expected value) and displays the most significant positions in a multiple sequence alignment. Positions with high Z-scores are predicted to determine functional specificity.

\section{RNA isolation, DNase I treatment, cDNA synthesis and semi-quantitative RT-PCR analysis}

Total RNA from all samples was isolated using TRIZOL reagent according to the manufacturer's protocol (Invitrogen). RNA integrity, RNA concentration, RNA quality, DNase 1 treatment and cDNA synthesis were performed as previously described [66]. Two representatives of each class of NBS-LRR R genes were selected for expression analysis. Gene-specific primer pairs were designed using Primer5.0 software. A total of 13 pairs of CaRGA-specific primers were obtained (Additional file 5). Nine CaRGAs (i.e. CaRGA23, CaRGA38, CaRGA18, CaRGA36, CaRGA51, CaRGA13, CaRGA14, CaRGA49 and CaRGA44) were selected from NCBI. The remaining four CaRGAs (i.e. CaRGA03, CaRGA05, CaRGA04 and CaRGA01) were selected from PCR amplification. Subsequently, we analyzed the visualization of amplicon fragments to verify whether these primers were specific. Primers that exhibited the electrophoresis pattern of a single amplicon with the correct predicted size were considered CaRGA-specific primers. RT-PCR reactions were carried out using an Eppendorf PCR system 5331 cycler. The cycling program was as follows: $10 \mathrm{~min}$ at $94^{\circ} \mathrm{C}$, 30 cycles of $45 \mathrm{~s}$ at $94^{\circ} \mathrm{C}, 45 \mathrm{~s}$ at $55^{\circ} \mathrm{C}$ and $1 \mathrm{~min}$ at $72^{\circ} \mathrm{C}$ and a $7 \mathrm{~min}$ extension at $72^{\circ} \mathrm{C}$. The glyceraldehyde-3phosphate dehydrogenase (GAPDH) gene was used as a reference [66].

\section{Quantitative RT-PCR and data analyses}

Primer specificity for quantitative RT-PCR was further confirmed by analyzing melting curves. Primers corresponding to the melting curves that yielded single sharp peaks were used for quantitative RT-PCR analysis. Realtime PCR reactions were carried out in a total volume of $25 \mu \mathrm{L}$ containing $12.5 \mu \mathrm{L}$ of $2 \times$ SYBRGreen PCR MasterMix (Applied Biosystems), $1 \mu \mathrm{L}$ of each primer, $1 \mu \mathrm{L}$ of template (10× diluted cDNA from samples) and $9.5 \mu \mathrm{L}$ of sterile distilled water. The thermal conditions were as follows: $95^{\circ} \mathrm{C}$ for $10 \mathrm{~min}$, followed by 40 cycles at $95^{\circ} \mathrm{C}$ for $15 \mathrm{~s}$ and a final step at $60^{\circ} \mathrm{C}$ for $1 \mathrm{~min}$. Quantification analysis was performed through the comparative CT method. All reactions were performed in triplicate in 96-well reaction plates using an iQ5 machine (Bio-Rad). Two independent replicates were performed. GAPDH was used as a reference gene for the expression analysis of the pepper CaRGA genes [66].

\section{Additional files}

Additional file 1: PCR amplification products generated by two pairs of degenerate primers in pepper. Lanes $A$ and $B$ were products of the primer combinations Ploop-1 and GLPL-1 and Ploop-2 and GLPL-2, respectively; M: marker 2000. 


\section{Additional file 2: DNA and protein sequences of the CaRGAs in} pepper.

Additional file 3: Site-specific profile of predicted critical amino acid residues responsible for the functional divergence between the non-TIR and TIR-NBS RGA subfamilies, measured at each site using the posterior probability of being associated with functional divergence. The arrows point to 13 amino acid residues at which functional divergence between the two subfamilies was predicted.

Additional file 4: Illustration of specificity-determining positions (SDPs) in the non-TIR-and TIR-NBS-LRR subfamilies in pepper. '-' indicates gaps in the alignment. Possible SDPs that might determine functional specificity are highlighted in red and indicated by arrows.

Additional file 5: (A) Degenerate primer sequences used in DNA amplification of NBS-LRR CaRGAs from pepper. (B) qRT-PCR amplification was used to determine the expression profiles of cloned CaRGAs using the corresponding CaRGA-specific primers.

\section{Competing interests}

The authors declare that they have no competing interests.

\section{Authors' contributions}

HJW and WY participated in conceiving the paper, primer design, sequence analysis, and drafting the final manuscript. MYR and QJY participated in DNA extraction and PCR amplification. RQW, ZML and SJL participated in bioinformatics, and modified the final manuscript. JZ, GZZ and ZPY participated in conceiving the study, and modified the final manuscript. YJY critically reviewed the manuscript and gave financial support to the study. All authors read and approved the final manuscript.

\section{Acknowledgements}

We thank Prof. Zhiping Deng for reading this paper from Institute of Virology and Biotechnology, Zhejiang Academy of Agricultural Sciences, Hangzhou, China. This research was partially supported by the General Program from the National Natural Science Foundation of China (31071800); Zhejiang Provincial Natural Science Foundation of China (LQ12C15004) and Public Agricultural Technology Research (2011C22007); Breeding of Vegetable Varieties in Zhejiang Province (2009C02006-1) and Technological System of Ordinary Vegetable Industry.

Received: 12 April 2012 Accepted: 12 September 2012 Published: 21 September 2012

\section{References}

1. Flor $\mathrm{HH}$ : The current status of gene for gene concept. Ann Rev Phytopathol 1971, 9:275-296.

2. Dangl JL, Jones JDG: Plant pathogens and integrated responses to infection. Nature 2001, 411:826-833.

3. Meyers BC, Kozik A, Griego A, Kuang H, Michelmore RW: Genome wide analysis of NBS-LRR-encoding genes in Arabidopsis. Plant Cell 2003, 15:809-834

4. DeYoung BJ, Innes RW: Plant NBS-LRR proteins in pathogen sensing and host. Nat Immunol 2006, 7:1243-1249

5. McHale L, Tan X, Koehl P, Michelmore RW: Plant NBS-LRR proteins: adaptable guards. Genome Biol 2006, 7:212.

6. Liu JL, Liu XL, Dai LY, Wang GL: Recent progress in elucidating the structure, function and evolution of disease resistance genes in plants. J Genet Genomics 2007, 34:765-776.

7. Holub EB: The arms race is ancient history in Arabidopsis, the wildflower Nat Rev Genet 2001, 2:516-527.

8. Yue JX, Meyers BC, Chen JQ, Tian DC, Yang SH: Tracing the origin and evolutionary history of plant nucleotide-binding site-leucine-rich repeat (NBS-LRR) genes. New Phytol 2012, 193:1049-1063.

9. Meyers BC, Dickerman AW, Michelmore RW, Sivaramakrishnan S, Sobral BW, Young ND: Plant disease resistance genes encode members of an ancient and diverse protein family within the nucleotide-binding super family. Plant J 1999, 20:317-332.

10. Tameling WI, Elzinga SD, Darmin PS, Vossen JH, Takken FL, Haring MA, Cornelissen $\mathrm{BJ}$ : The tomato $\mathrm{R}$ gene products $\mathrm{I}-2$ and $\mathrm{Mi}-1$ are functional ATP binding proteins with ATPase activity. Plant Cell 2002, 14:2929-2939.
11. Kobe $B$, Deisenhofer J: A structural basis of the interactions between leucine-rich repeats and protein ligands. Nature 1995, 374:183-186.

12. Leister RT, Katagiri F: A resistance gene product of the nucleotide binding site-leucine rich repeats class can form a complex with bacterial avirulence proteins in vivo. Plant J 2000, 22:345-354

13. Yu YG, Buss GR, Saghai Maroof MA: Isolation of a superfamily of candidate disease-resistance genes in soybean based on a conserved nucleotidebinding site. Proc Natl Acad Sci USA 1996, 93:11751-11756.

14. Gentzbittel L, Mouzeyar S, Badaoui S, Mestries E, Vear F, Tourvieille de Labrouhe D, Nicolas P: Cloning of molecular markers for disease resistance in sunflower, Helianthus annuus L. Theor Appl Genet 1998, 96:519-525.

15. Pan QL, Wendel J, Fluhr R: Divergent evolution of plant NBS LRR resistance gene homologues in dicot and cereal genomes. J Mol Evol 2000, 50:203-213.

16. Tian YY, Fan $L$, Thurau T, Jung C, Cai DG: The absence of TIR-type resistance gene analogues in the sugar beet (Beta vulgaris L.) genome. $J$ Mol Evol 2004, 58:40-53.

17. Wan HJ, Zhao ZG, Malik AA, Qian CT, Chen JF: Identification and characterization of potential NBS-encoding resistance genes and induction kinetics of a putative candidate gene associated with downy mildew resistance in Cucumis. BMC Plant Biol 2010, 10:186.

18. Zhang $\mathrm{HL}$, Wang YJ, Zhang $\mathrm{CH}$, Wang XP, Li HE, Xu WR: Isolation, characterization and expression analysis of resistance gene candidates in pear (Pyrus spp.). Sci Horticul 2011, 127:282-289.

19. Mutlu N, Miklas PN, Coyne DP: Resistance gene analog polymorphism (RGAP) markers co-localize with disease resistance genes and QTL in common bean. Mol breeding 2006, 17:127-135.

20. Cannon SB, Zhu H, Baumgarten AM, Spangler R, May G, Cook DR, Young ND: Diversity, distribution and ancient taxonomic relationships within the TIR and non-TIR NBS-LRR resistance gene subfamilies. J Mol Evol 2002, 54:548-562.

21. Speulman E, Bouchez D, Holub EB, Beynon JL: Disease resistance gene homologs correlate with disease resistance loci of Arabidopsis thaliana. Plant J 1998, 14:467-474

22. Ashfield T, Bocian A, Held D, Henk AD, Marek LF, Danesh D, Penūela S, Meksem K, Lightfoot DA, Young ND, Shoemaker RC, Innes RW: Genetic and physical localization of the soybean $R p g$ 1- $b$ disease resistance gene reveals a complex locus containing several tightly linked families of NBSLRR genes. Mol Plant Microbe Interact 2003, 16:817-826.

23. Radwan O, Bouzidi MF, Nicolas P, Mouzeyar S: Development of PCR markers of the PI5/PI8 locus for resistance to Plasmopara halstedii in sunflower, Helianthus annuus L. from complete CC-NBS-LRR sequences. Theor Appl Genet 2004, 109:176-185.

24. Hulbert SH, Webb CA, Smith SM, Sun Q: Resistance gene complexes: Evolution and utilization. Annu Rev Phytopathol 2001, 39:285-312.

25. Richly $E$, Kurth J, Leister D: Mode of amplification and reorganization of resistance genes during recent Arabidopsis thaliana evolution. Mol Biol Evol 2002, 19:76-84.

26. Zhou T, Wang Y, Chen JQ, Araki H, Jing Z, Jiang K, Shen J, Tian D: Genomewide identification of NBS genes in rice reveals significant expansion of divergent non-TIR NBS Genes. Mol Genet Genomics 2004, 271:402-415.

27. Mondragón-Palomino M, Meyers BC, Michelmore RW, Gaut BS: Patterns of positive selection in the complete NBS-LRR gene family of Arabidopsis thaliana. Genome Res 2002, 12:1305-1315.

28. Yang SH, Zhang XH, Yue JX, Tian DC, Chen JQ: Recent duplications domainate NBS-encoding gene expansion in two woody species. Mol Genet Genomics 2008, 280:187-198.

29. Xu Q, Wen XP, Deng XX: Isolation and TIR and nonTIR NBS-LRR resistance gene analogues and identification of molecular markers linked to a powdery mildew resistance locus in chestnut rose (Rosa roxburghii Tratt). Theor Appl Genet 2005, 111:819-830.

30. Xu Q, Wen XP, Deng XX: Phylogenetic and evolutionary analysis of NBS encoding genes in Rosaceae fruit crops. Mol Phylogenet Evol 2007, 44:315-324

31. Römer $P$, Hahn $S$, Jordan T, Strauß T, Bonas U, Lahaye T: Plant pathogen recognition mediated by promoter activation of the pepper Bs3 resistance gene. Science 2007, 318:645-648.

32. Tai TH, Dahlbeck D, Clark ET, Gajiwala P, Pasion R, Whalen MC, Stall RE, Staskawicz BJ: Expression of the Bs2 pepper gene confers resistance to bacterial spot disease in tomato. Proc Natl Acad Sci 1999, 96:14153-14158. 
33. Chen R, Li H, Zhang L, Zhang J, Xiao J, Ye Z: CaMi, a root-knot nematode resistance gene from hot pepper (Capsium annuum L.) confers nematode resistance in tomato. Plant Cell Rep 2007, 26:895-905.

34. Egea-gilabert C, Dickinson MJ, Bilotti G, Candela ME: Isolation of resistance gene analogs in pepper using modified AFLPs. Biol Plantarum 2003, 47:27-32.

35. Pflieger S, Lefebvre V, Caranta C, Blattes A, Goffinet B, Palloix A: Disease resistance gene analogs as candidates for QTLs involved in pepperpathogen interactions. Genome 1999, 42:1100-1110.

36. Kochieva EZ, Ryzhova NN: Analysis of resistance gene family diversity in pepper (Capsicum annuum). Biochem Biophy Mol Biol 2009, 425:256-258.

37. Zhang LY, Chen RG, Zhang JH: Cloning and analysis of resistance gene analogs from pepper (Capsicum annuum L.). Agr Sci China (in Chinese) 2008, 41:169-175.

38. Noir S, Combes M-C, Anthony F, Lashermes P: Origin, diversity and evolution of NBS-type disease-resistance gene homologues in coffee trees (Coffea L.). Mol Gen Genomics 2001, 265:654-662.

39. Deng Z, Huang S, Ling P, Chen C, Yu C, Weber CA, Moore GA, Gmitter FG: Cloning and characterization of NBS-LRR class resistance-gene candidate sequences in citrus. Theor Appl Genet 2000, 101:814-822.

40. van der Biezen EA, Jones JDG: The NB-ARC domain: a novel signalling motif shared by plant resistance gene products and regulators of cell death in animals. Curr Biol 1998, 8:R226-R227.

41. Aravind L, lyer LM, Leipe DD, Koonin EV: A novel family of P-loop NTPases with an unusual phyletic distribution and transmembrane segments inserted within the NTPase domain. Genome Biol 2004, 5:R30.

42. Leipe DD, Koonin EV, Aravind L: STAND, a class of P-loop NTPases including animal and plant regulators of programmed cell death: multiple, complex domain architectures, unusual phyletic patterns, and evolution by horizontal gene transfer. J Mol Biol 2004, 343:1-28.

43. Tamura K, Peterson D, Peterson N, Stecher G, Nei M, Kumar S: MEGA5: Molecular evolutionary genetics analysis using maximum likelihood, evolutionary distance, and maximum parsimony methods. Mol Biol Evol 2011, 28:2731-2739.

44. Gu X: Statistical methods for testing functional divergence after gene duplication. Mol Biol Evol 1999, 16:1664-1674.

45. Gu X: A simple statistical method for estimating type-II (cluster-specific) functional divergence of protein sequences. Mol Biol Evol 2006, 23:1937-1945

46. Michelmore R, Meyers B: Clusters of resistance genes in plants evolve by divergent selection and birth-and-death process. Genome Res 1998, 8:1113-1130.

47. Martin GB, Brommonschenkel S, Chunwongse J, Frary A, Ganal MW, Spivey $R, W u T$, Earle ED, Tanksley SD: Map-based cloning of a protein kinase gene conferring disease resistance in tomato. Science 1993, 262:1432-1436.

48. Creevey CJ, McInerney JO: CRANN: Detecting adaptive evolution in protein-coding DNA sequences. Bioinformatics 2003, 19:1726.

49. Mazin PV, Gelfand MS, Mironov AA, Rakhmaninova AB, Rubinov AR, Russell $\mathrm{RB}$, Kalinina OV: An automated stochastic approach to the identification of the protein specificity determinants and functional subfamilies. Algorithm Mol Biol 2010, 5:29.

50. Thomma BP, Penninckx IA, Broekaer WF, Cammue BP: The complexity of disese signaling in Arabidopsis. Curr Opin Immunol 2011, 13:63-68.

51. Shirano Y, Kachroo P, Shah J, Klessig DF: A gain-of-function mutation in an arabidopsis Toll interleukin1 receptor-nucleotide binding site-leucinerich repeat type $\mathrm{R}$ gene triggers defense responses and results in enhanced disease resistance. Plant Cell 2002, 14:3149-3162.

52. Xiao SX, Brown EP, Brearley C, Turner JG: Enhanced transcription of the Arabidopsis disease resistance genes RPW8.1and RPW8.2 via a salicylic acid-dependent amplification circuit is required for hypersensitive cell death. Plant Cell 2003, 15:33-45.

53. Xiong QY, Wei L, Sen ZJ, Hong RM, Ping XL, Qing ZM: Molecular cloning and characterisation of a non-TIR-NBS-LRR type disease resistance gene analogue from sugarcane. Sugar Tech 2008, 10:71-73.

54. Wang BJ, Zhang ZG, Li XG, Wang YJ, He CY, Zhang JS, Chen SY: Cloning and analysis of a disease resistance gene homolog from soybean. Acta Botan Sin 2003, 45:864-870

55. Wang BJ, Wang YJ, Wang Q, Luo GZ, Zhang ZG, He CY, He SJ, Zhang JS, Gai $J Y$, Chen SY: Characterization of an NBS-LRR resistance gene homologue from soybean. J Plant Physiol 2004, 161:815-822.
56. Tian AG, Luo GZ, Wang YJ, Zhang JS, Gai JY, Chen SY: Isolation and characterization of a Pti1 homologue from soybean. J Exp Bot 2004, 396:535-537.

57. Bendahmane A, Querci M, Kanyuka K, Baulcombe DC: Agrobacterium transient expression system as a tool for isolation of disease resistance genes: application to the Rx2 locus in potato. Plant J 2000, 21:73-81.

58. Baulcombe DC: Fast forward genetics based on virus-induced gene silencing. Curr Opin Plant Biol 1999, 2:109-113.

59. Thompson JD, Gibson TJ, Plewniak F, Jeanmougin F, Higgins DG: The CLUSTAL_X windows interface: flexible strategies for multiple sequence alignment aided by quality analysis tools. Nucleic Acids Res 1997, 25:4876-4882.

60. van der Biezen EA, Jones JD: The NB-ARC domain: a novel signaling motif shared by plant resistance gene products and regulators of cell death in animals. Curr Biol 1998, 8:R226-R227.

61. Gu X, Vander Velden K: DIVERGE: phylogeny-based analysis for functionalstructural divergence of a protein family. Bioinformatics 2002, 18:500-501.

62. Nei M, Gojobori T: Simple methods for estimating the numbers of synonymous and nonsynonymous nucleotide substitutions. Mol Biol Evol 1986, 3:418-426.

63. Comeron JM: A method for estimating the numbers of synonymous and non-synonymous substitutions per site. J Mol Evol 1995, 41:1152-1159.

64. Comeron JM: K-Estimator: Calculation of the number of nucleotide substitutions per site and the confidence intervals. Bioinformatics 1999, 15:763-764

65. Librado P, Rozas J: DnaSP v5: a software for comprehensive analysis of DNA polymorphism data. Bioinformatics 2009, 25:1451-1452.

66. Wan HJ, Yuan W, Ruan MY, Ye QJ, Wang RQ, Li ZM, Zhou GZ, Yao ZP, Zhao J, Liu SJ, Yang YJ: Identification of reference genes for reverse transcription quantitative real-time PCR normalization in pepper (Capsicum annuum L.). Biochem Biophys Res Commun 2011, 416:24-30.

doi:10.1186/1471-2164-13-502

Cite this article as: Wan et al:: Analysis of TIR- and non-TIR-NBS-LRR disease resistance gene analogous in pepper: characterization, genetic variation, functional divergence and expression patterns. BMC Genomics 2012 13:502.

\section{Submit your next manuscript to BioMed Central and take full advantage of:}

- Convenient online submission

- Thorough peer review

- No space constraints or color figure charges

- Immediate publication on acceptance

- Inclusion in PubMed, CAS, Scopus and Google Scholar

- Research which is freely available for redistribution 